\title{
On the Mechanism of Lithium-Induced Diabetes Insipidus
} in Man and the Rat

\author{
John N. Forrest, Jr., Alan D. Cohen, Jorge Torretti, \\ Jonathan M. Himmelhoch, and Frankiln H. Epstein \\ From the Renal Section, Department of Medicine, and the Department of \\ Psychiatry, Yale-New Haven Hospital; and the West Haven Veterans \\ Administration Hospital, Yale University School of Medicine, \\ New Haven, Connecticut 06510
}

A в S.T R A C T The mechanism of lithium-induced diabetes insipidus was investigated in 96 patients and in a rat model. Polydipsia was reported by $40 \%$ and polyuria (more than 3 liter/day) by $12 \%$ of patients receiving lithium. Maximum concentrating ability after dehydration and vasopressin was markedly impaired in 10 polyuric patients and was reduced in 7 of 10 nonpolyuric patients studied before and during lithium therapy. Severe polyuria (more than 6 liter/day) was unresponsive to trials of vasopressin and chlorpropamide, but improved on chlorothiazide. Rats receiving lithium (3-4 meq $/ \mathrm{kg} /$ day) developed massive polyuria that was resistant to vasopressin, in comparison to rats with comparable polyuria induced by drinking glucose. Analysis of renal tissue in rats with lithium polyuria showed progressive increase in the concentration of lithium from cortex to papilla with a 2.9-fold corticopapillary gradient for lithium. The normal corticopapillary gradient for sodium was not reduced by lithium treatment. The polyuria was not interrupted by brief intravenous doses of vasopressin $(5-10 \mathrm{mU} / \mathrm{kg})$ or dibutyryl cyclic AMP $(10-15 \mathrm{mg} / \mathrm{kg})$ capable of reversing water diuresis in normal and hypothalamic diabetes insipidus rats (Brattleboro strain). The present studies suggest that nephrogenic diabetes insipidus is a common finding after lithium treatment and results

This work was presented in part at the Annual Meeting of the American Society of Nephrology, Washington, D. C., November, 1971; and the 5th International Congress of Nephrology, Mexico City, October, 1972.

Dr. Forrest was a Research and Education Associate of the Veterans Administration.

Dr. Cohen was supported by a fellowship from the Medical Research Council of Canada.

Received for publication 26 March 1973 and in revised form 8 October 1973. in part from interference with the mediation of vasopressin at a step distal to the formation of $3^{\prime}, 5^{\prime}$ cyclic AMP.

\section{INTRODUCTION}

The effects of lithium in man received little attention until the recent widespread use of its salts in the treatment of affective disorders (1-4). Several reports have described a reversible polyuria unresponsive to vasopressin in patients receiving lithium (5-7). Lithium has been reported to inhibit the antidiuresis normally produced by vasopressin in water-loaded rats (8), to inhibit various effects of vasopressin and $3^{\prime} 5^{\prime}$ cyclic AMP in toad urinary bladders (7-10), and to interfere with the stimulation of adenyl cyclase by vasopressin in rabbit and human renal medullary tissue (11-12). We report here a series of investigations on the effects of lithium on the renal concentrating mechanism of man and the rat.

\section{METHODS}

Human studies. 96 consecutive patients attending a lithium outpatient clinic were studied. Patients were questioned about any change in their water intake and urine output since the beginning of lithium therapy. Daily urine volumes were determined in patients reporting polyuria. Renal concentration tests were performed in polyuric patients and in 10 patients before and after 8-12 wk of lithium carbonate therapy, $900-2,400 \mathrm{mg} /$ day. Three patients with severe polyuria (6-9 liter/day) were studied in a clinical research unit. All medications except lithum were discontinued and the patients were placed on a 4-g $\mathrm{NaCl}$ diet with monitoring of daily fluid balance. The effects of 4-7 days treatment with vasopressin, chlorpropamide, and chlorothiazide were investigated. 
TABLE I

Symptoms in 96 Patients with Affectice Disorders Receiving Lithium Therapy $\left(\mathrm{Li}_{2} \mathrm{CO}_{3}, 900-1,800 \mathrm{mg} /\right.$ day $)$

\begin{tabular}{lcc}
\hline \multicolumn{1}{c}{ symptoms } & $\begin{array}{c}\text { Number } \\
\text { patients } \\
\text { reporting }\end{array}$ & $\%$ \\
\hline Increased thirst and water intake & 36 & 40 \\
Polyuria ( $>3$ liter/day) by measurement & 11 & 12 \\
Unmeasured increase in urine volume & 19 & 20 \\
\hline
\end{tabular}

A standardized test of renal concentrating ability $\left(U_{\max }\right)^{1}$ was used in all patients (13). Patients were deprived of fluid from 6 p.m. on the evening before the test. Beginning at 6 or 7 a.m., urine specimens were collected each hour, and the volume and osmolality measured. When the osmolality of the urine ( $\left.U_{o s m}\right)$ had reached a constant plateau (16-18 h of fluid deprivation), plasma was collected for osmolality, and $5 \mathrm{U}$ of aqueous vasopressin (Pitressin, Parke, Davis \& Co., Detroit, Mich.) were injected subcutaneously. A final urine was collected $1 \mathrm{~h}$ after the vasopressin injection. Osmolality of plasma and urine was measured in duplicate on a Fiske osmometer (Fiske Associates, Inc., Uxbriclge, Mass.).

Animal studies. Polyuria was induced in 130-170-g Sprague-Dawley rats by daily intraperitoneal injection of isotonic lithium chloride $(0.15 \mathrm{M}), 3-4 \mathrm{meq} \mathrm{Li}^{+} / \mathrm{kg}$ body wt/day. In most experiments rats were fed a prepared normal diet containing $6.04 \mathrm{~g} \mathrm{NaCl}, 11.6 \mathrm{~g} \mathrm{~K}_{2} \mathrm{HPO}_{4}$, and $30.37 \mathrm{~g}$ mineral mixture $/ \mathrm{kg}$ diet. In control rats a water diuresis, producing comparable polyuria in $24 \mathrm{~h}$, was established by addition of glucose to the drinking water for 1 wk before testing. Response to vasopressin was tested by administration of $1 \mathrm{U}$ of well mixed vasopressin tannate in oil every $4 \mathrm{~h}$ for three doses.

Analysis of renal tissue for water and electrolyte content was performed in normal untreated rats and in chronic (7-day) lithium-treated rats with polyuria. Serum lithium concentration at the time of study was varied in three groups of lithium-treated rats by administering the last lithium dose 24,8 , or $4 \mathrm{~h}$ before sacrifice. Food and water were withheld from all animals for $12 \mathrm{~h}$ before sacrifice. Electrolyte content of renal tissue was analyzed by methods described previously (14). I.ithium was measured by atomic absorption spectrophotometry.

Acute studies with intravenous injections $(0.5 \mathrm{ml}$ volume) of vasopressin $(5-10 \mathrm{mU} / \mathrm{kg}$ in $5 \mathrm{~min})$ and $\mathrm{di}$ butyryl cyclic AMP $(15-20 \mathrm{mg} / \mathrm{kg}$ in $5 \mathrm{~min})$ were performed in normal rats, lithium-treated rats with polyuria, and rats with hereditary hypothalamic diabetes insipidus (Brattleboro strain). Homozygous Brattleboro rats excreting more than $50 \%$ of body weight as urine/day were selected for study. Lithium rats received their daily lithium dose $2 \mathrm{~h}$ before study. Animals were anesthetized with Inactin (Promonta, Hamburg, West Germany) and a tracheostomy was performed. Catheters were placed in

'Abbreviations used in this paper: cyclic AMP, 3' 5' AMP; dibutyryl cyclic AMP, $\mathrm{N}^{6} 2^{\prime}$-0-dibutyryl AMP ; GFR, glomerular filtration rate; TSH, thyroid-stimulating hormone; $\mathrm{U}_{\mathrm{max}}$, maximum urine osmolality; $\mathrm{U}_{\mathrm{osm}}$, urine osmolality. both external jugular veins and bladder. Urine was collected directly into $1-\mathrm{ml}$ silicone-coated pipettes during 10 -min collection periods. A water diuresis was established by intravenous loading over $20 \mathrm{~min}$ with a volume equal to $6 \%$ of body weight of a hypotonic solution containing $0.075 \mathrm{M} \mathrm{NaCl}$ and $1.75 \%$ glucose, before a constant infusion of the same solution at $0.212 \mathrm{ml} / \mathrm{min}$. In separate experiments in Brattleboro rats, serial measurements of glomerular filtration rate (GFR) were made during infusion of higher doses of both vasopressin $(13 \mathrm{mU} / \mathrm{kg} / 60)$ min) and dibutyryl cyclic AMP $(67-100 \mathrm{mg} / \mathrm{kg} / 60 \mathrm{~min})$. GFR was determined by $\left[{ }^{3} \mathrm{H}\right]$ inulin clearance with a constant intravenous infusion of $50 \mu \mathrm{Ci} / \mathrm{h}$ after a loading dose of $50 \mu \mathrm{Ci}$.

\section{RESULTS}

\section{Patient studies}

Symptoms and renal concentrating ability. An increase in thirst and water intake noted during lithium therapy was reported by $40 \%$ of 96 patients (Table I). In 11 patients $(12 \%)$, polyuria greater than $3,000 \mathrm{ml} /$ day was documented by direct measurement of urine volume. An additional $20 \%$ of patients reported an unmeasured increase in urine volume. In all patients serum lithium concentrations were in the normal therapeutic range $(0.5-1.5 \mathrm{meq} / \mathrm{liter})$. Serum potassium and calcium concentrations were normal in all patients. There was no correlation between serum lithium concentrations and the severity of polyuria. Since phenothiazine preparations have been reported to depress antidiuretic hormone secretion (15), all medications except lithium were usually discontinued $1 \mathrm{wk}$ before measurement of concentrating ability.

A marked impairment of renal concentrating ability was demonstrated in 10 polyuric patients studied (Table II). The urine of patients 1-4 remained hypo-

TABLE II

$U_{\max }$ in Patients with Lithium-induced Polyuria

\begin{tabular}{|c|c|c|c|c|}
\hline & $\mathrm{U}_{\max }$ & $\mathrm{U}_{\max }$ & & \\
\hline Patient & $\begin{array}{l}14-18 \mathrm{~h} \\
\text { dehydra- } \\
\text { tion }\end{array}$ & $\begin{array}{c}\text { Dehydration } \\
\text { + vaso- } \\
\text { pressin }\end{array}$ & $\begin{array}{c}\text { Uosn } \\
\% \\
\text { Change* }\end{array}$ & $\begin{array}{c}\text { before } \\
\text { vaso- } \\
\text { pressin }\end{array}$ \\
\hline 1 & 180 & 288 & +60 & (310) \\
\hline 2 & 172 & 214 & +24 & (304) \\
\hline 3 & 265 & 210 & -21 & (305) \\
\hline 4 & 247 & 291 & +18 & (295) \\
\hline 5 & 377 & 479 & +27 & (299) \\
\hline 6 & 423 & 668 & +58 & (290) \\
\hline 7 & 623 & 664 & +7 & (291) \\
\hline 8 & 471 & 478 & +1 & $(312)$ \\
\hline 9 & 507 & 585 & +15 & (292) \\
\hline 10 & 526 & 588 & +12 & (290) \\
\hline $\begin{array}{l}\text { Mean } \\
\pm \text { SEM }\end{array}$ & $379 \pm 49$ & $446 \pm 57$ & & $298 \pm 2.7$ \\
\hline
\end{tabular}

* Percent change in Uosm comparing dehydration and vasopressin to dehydration only.

Posm, plasma osmolality. 
tonic to plasma despite prolonged dehydration with serum osmolalities of $295-310 \mathrm{mosmol} / \mathrm{kg}$. Six patients showed a spectrum of concentrating defects with $U_{\max }$ ranging from 478-668 mosmol/ $\mathrm{kg}$ after dehydration and vasopressin. Of special interest were two patients, 1 and 6, who showed substantial increase (60 and 58\%) in $U_{\text {osm }}$ when vasopressin was given after dehydration. In these patients, lithium may have inhibited the synthesis or release of vasopressin.

In 10 additional patients the effect of lithium on maximum concentrating ability was studied prospectively with measurement of $U_{\max }$ before and after 8-12 wk on lithium therapy (Fig. 1). Maximum concentrating ability was significantly reduced after lithium in this group of patients, with $U_{\max }$ (mean $\pm S E M$ ) declining from $1,001 \pm 47$ to $845 \pm 33 \mathrm{mosmol} / \mathrm{kg}$.

Response to therapy for diabetes insipidus. Response to therapy for diabetes insipidus was evaluated in three patients with severe, symptomatic polyuria $(6,000-9,200 \mathrm{ml} /$ day $)$. Studies were performed on a clinical research ward, with monitoring of fluid balance on a 4-g $\mathrm{NaCl}$ diet. After a control period of 4 days, each patient received $5 \mathrm{U}$ of well mixed vasopressin tannate in oil for 4 days, followed by chlorpropamide, $500-750 \mathrm{mg}$ daily for 4 days, and chlorothiazide, $0.5-1.0 \mathrm{~g}$ daily for 7 days. Mean urine output and osmolality for each period are shown in Fig. 2. Urine volume was not significantly reduced after vasopressin tannate or chlorpropamide in any patient and osmolalities of 24-h urines were unaffected by these agents. All patients had a marked reduction of polyuria after chlorothiazide administration (0.5-1.0 g/day), with improvement occurring by 2-3 days of treatment. A slight reduction in body weight (mean 1.7\%) oc-

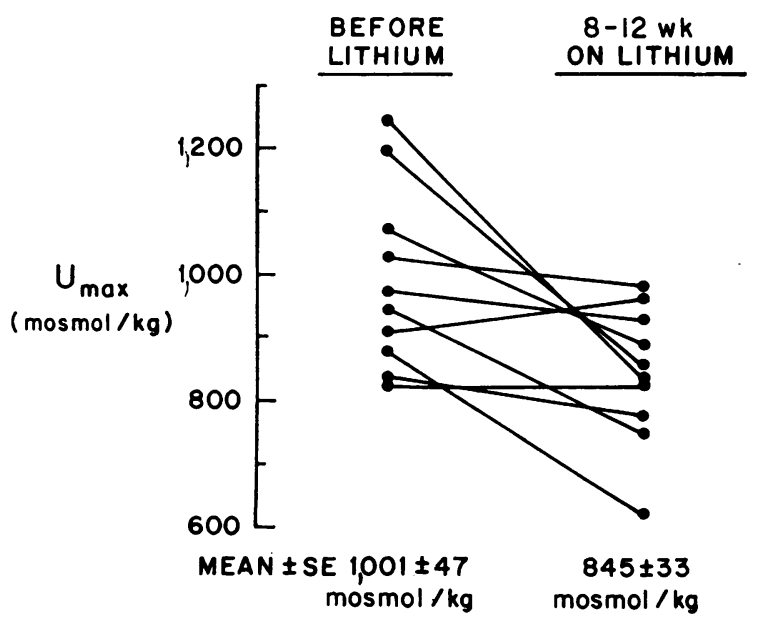

Figure $1 U_{\max }$ in 10 patients without polyuria studied before and during lithium treatment. Differences between means determined by paired $t$ test. $P<0.01$.

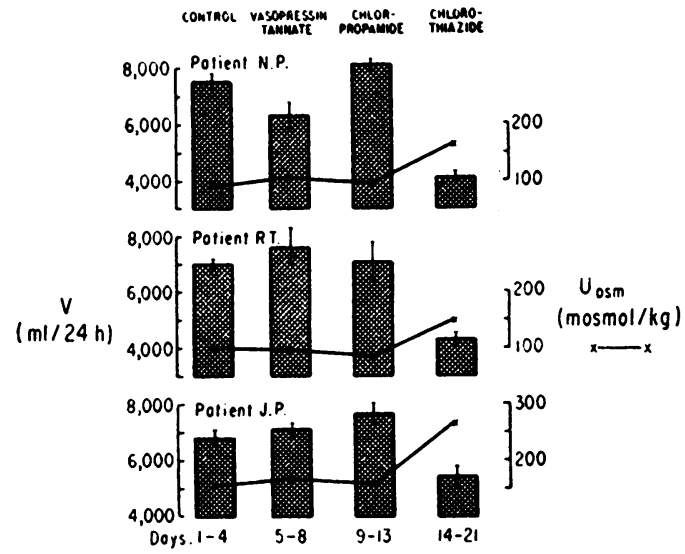

FIGURE 2 Effect of treatment with vasopressin tannate, chlorpropamide, and chlorothiazide on urine volume and $\mathrm{U}_{\mathrm{osm}}$ in three patients with lithium-induced diabetes insipidus. Values are mean $\pm \mathrm{SEM}$.

curred during treatment. Mean Uosm increased significantly in each patient receiving chlorothiazide though it did not rise above the osmolality of plasma.

\section{Animal studies}

Response to vasopressin. The mechanism of lithium polyuria was investigated further in Sprague-Dawley rats given daily intraperitoneal injections of isotonic lithium chloride, 3-4 meq lithium $/ \mathrm{kg} /$ day. Urine volume was increased significantly on the first day of lithium administration (Fig. 3). By 4-5 days lithium-treated rats developed profound polyuria, with daily urinary output equal to $50-70 \%$ of body weight. Control rats given isotonic sodium chloride, $3-4 \mathrm{meq} / \mathrm{kg} / \mathrm{day}$, had no increase in urine volume.

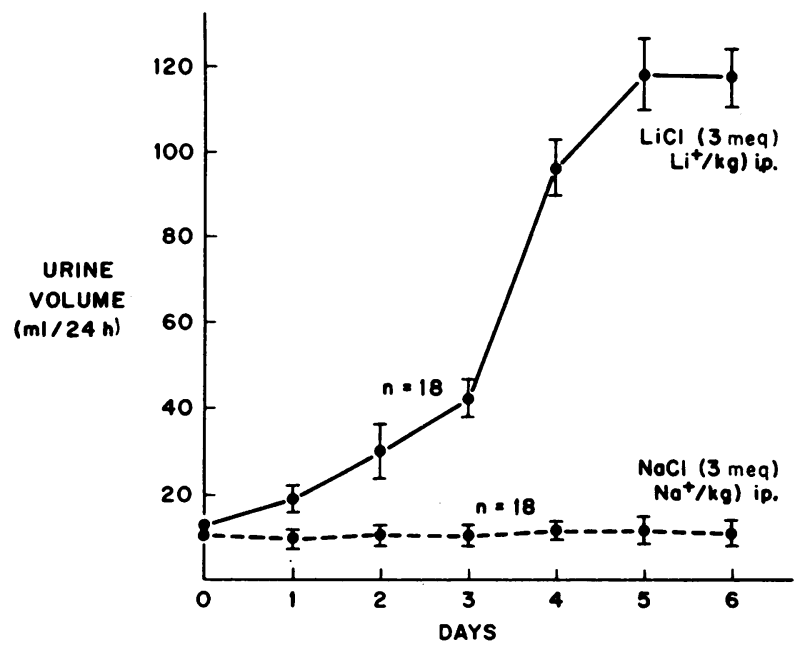

Figure 3 Development of lithium polyuria in $170-\mathrm{g}$ rats receiving lithium chloride, $3 \mathrm{meq}$ lithium $/ \mathrm{kg} /$ day. 
TABLE III

Renal Tissue Analysis in Rats with Lithium-Induced Polyuria and Control Rats

\begin{tabular}{|c|c|c|c|c|c|c|c|c|}
\hline \multirow[b]{2}{*}{ Groups } & \multirow[b]{2}{*}{ Tissue } & \multicolumn{2}{|c|}{ Water content } & \multicolumn{2}{|c|}{$\mathrm{Na}^{+}$} & \multicolumn{2}{|c|}{$\mathrm{K}^{+}$} & \multirow{2}{*}{$\frac{\mathrm{Li}^{+}}{\mathrm{Li}^{+} \text {rats }}$} \\
\hline & & $\mathrm{Li}^{+}$rats & Controls & $\mathrm{Li}^{+}$rats & Controls & $\mathrm{Li}^{+}$rats & Controls & \\
\hline
\end{tabular}

Group 1. Lithium rats (serum lithium $0.69 \pm 0.09 \mathrm{meq} /$ liter) and controls

$\begin{array}{llllllll}\text { Cortex } & 77.1 \pm 0.1 & 77.2 \pm 0.1 & 124 \pm 1.9 & 119 \pm 4.1 & 80.6 \pm 0.9 & 85.1 \pm 2.7 & 1.2 \pm 0.1 \\ \text { Red medulla } & 83.9 \pm 0.4 & 85.3 \pm 0.4 & 154 \pm 4.2 & 174 \pm 10.3 & 91.0 \pm 2.5 & 80.4 \pm 3.1 & 2.8 \pm 0.3 \\ \text { Papilla } & 85.9 \pm 0.2 & 84.1 \pm 0.5 & 206 \pm 15.7 & 198 \pm 15.4 & 78.2 \pm 4.4 & 87.1 \pm 4.9 & 2.2 \pm 0.08\end{array}$

Group 2. Lithium rats (serum lithium $1.5 \pm 0.05 \mathrm{meq} /$ liter) and controls

\begin{tabular}{lrrrrrrr} 
Cortex & $77.3 \pm 0.1$ & $77.8 \pm 0.2$ & $100 \pm 1.3$ & $99 \pm 2.1$ & $70.0 \pm 0.9$ & $70.0 \pm 1.0$ & $2.5 \pm 0.1$ \\
Red medulla & $80.6 \pm 0.3$ & $80.7 \pm 0.8$ & $88 \pm 2.7$ & $95 \pm 2.4$ & $90.0 \pm 2.8$ & $94.5 \pm 1.3$ & $4.5 \pm 0.5$ \\
White medulla & $84.6 \pm 0.3$ & $85.6 \pm 0.3$ & $150 \pm 2.2$ & $156 \pm 2.8$ & $77.5 \pm 3.5$ & $72.0 \pm 1.9$ & $5.4 \pm 0.4$ \\
Papilla & $85.9 \pm 0.4$ & $87.1 \pm 0.4$ & $213 \pm 6.4$ & $205 \pm 7.7$ & $67.0 \pm 8.8$ & $69.0 \pm 4.0$ & $5.6 \pm 0.5$ \\
\hline
\end{tabular}

All values are mean $\pm \mathrm{SEM}$ of four analyses with tissue of three animals (six kidneys) pooled per analysis.

Since polyuria and a defect in urinary concentration resistant to vasopressin might conceivably have resulted from primary polydipsia and excessive intake of water, the concentrating ability of lithium-treated rats was compared to that of rats in which comparable polyuria had been induced by addition of glucose to drinking water (Fig. 4). Dietary intake of sodium and protein was similar in both groups and 24-h urine volumes on the day before the experiment were also comparable (lithium rats $92.0 \pm 12.5 \mathrm{ml} / 24 \mathrm{~h}$ vs. glucose-drinking rats $88.7 \pm 10.2 \mathrm{ml} / 24 \mathrm{~h}$. Vasopressin tannate in oil $(1 \mathrm{U} / 150 \mathrm{~g}$ rat $)$ was given subcutaneously at 4-h intervals for three doses. Glucose-drinking polyuric rats showed a blunted but definite response to the first injection of vasopressin (Uosm $520 \pm 22$ mosmol//

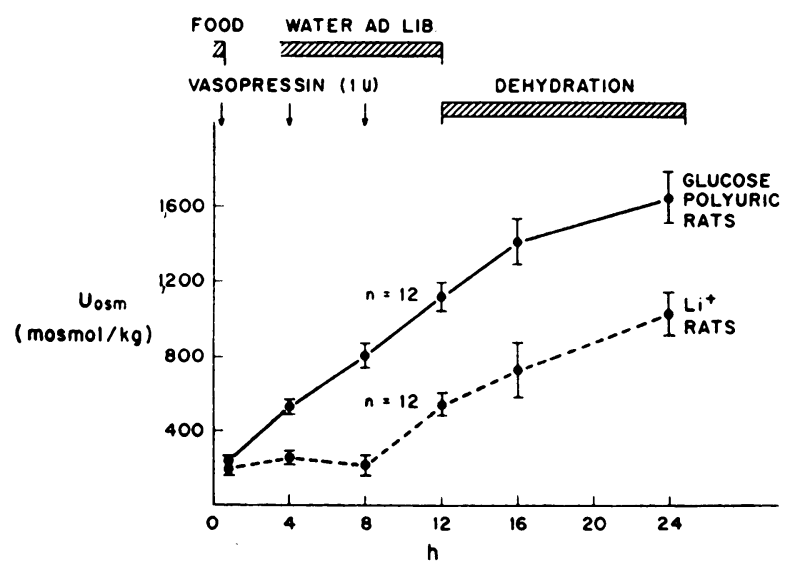

Figure 4 Effect of repeated doses of vasopressin tannate and dehydration on $\mathrm{U}_{\mathrm{osm}}$ in lithium-polyuric rats and rats with comparable polyuria induced by glucose drinking. Values are mean \pm SEM. All differences are significant at $P<0.001$. $\mathrm{kg}$ at $4 \mathrm{~h}$ ) with subsequent $\mathrm{U}_{\mathrm{osm}}$ of $800 \pm 31$ and $1,120 \pm 60$ at 8 and $12 \mathrm{~h}$. Lithium-polyuric rats showed no response to this large dose of vasopressin at 4 or $8 \mathrm{~h}$ but concentrated to $520 \pm 27 \mathrm{mosmol} / \mathrm{kg}$ at $12 \mathrm{~h}$ after three doses of vasopressin. In both groups there was a further increase in Uosm after $12 \mathrm{~h}$ of dehydration. Lithium rats achieved a maximum urine concentration of $1,000 \mathrm{mosmol} / \mathrm{kg}$, a value comparable to that

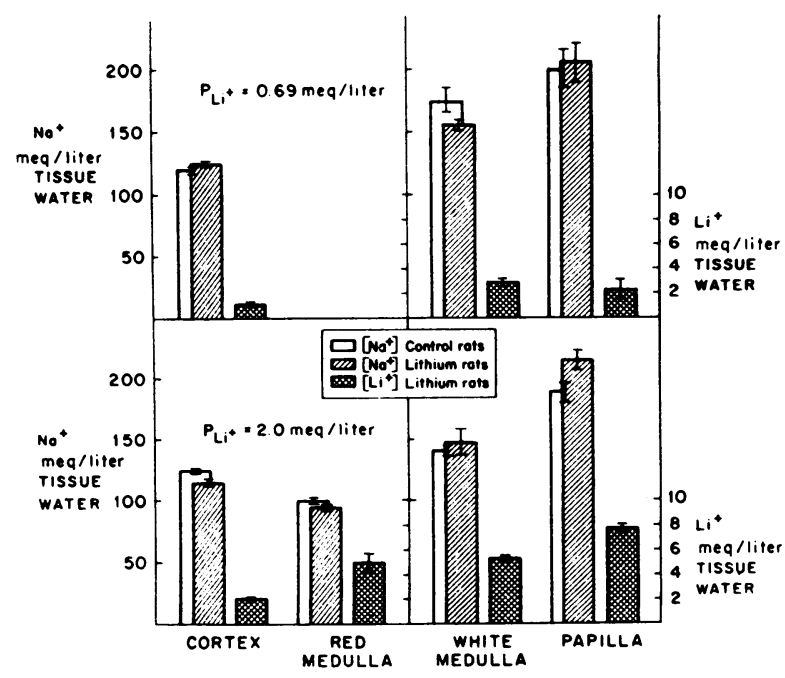

Figure 5 Renal tissue analysis for sodium and lithium content in lithium-polyuric rats and normal controls. Upper graph shows values for group 1 rats with lowest plasma lithium concentrations $(0.69 \mathrm{meq} / \mathrm{liter})$ and lower graph shows group 3 rats with highest plasma lithium concentrations $(2.0 \mathrm{meq} / \mathrm{liter})$. Open bars represent tissue sodium content in control rats, single-crossed bars tissue sodium in lithium rats, and double-crossed bars tissue lithium in lithium rats. Values are mean \pm SEM. 


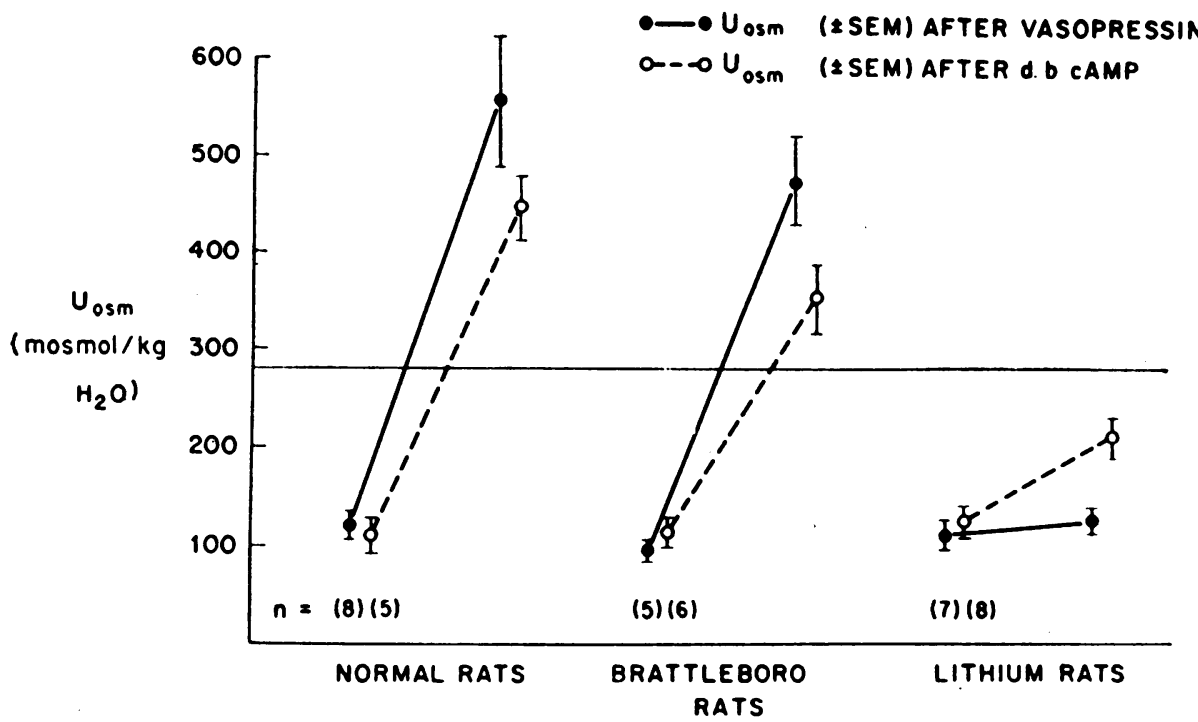

FIGURE 6 Maximum effect of single intravenous injection of vasopressin $(5-10 \mathrm{mU} / \mathrm{kg})$ and dibutyryl cyclic $(\mathrm{db})$ AMP $(15-20 \mathrm{mg} / \mathrm{kg})$ on $U_{o s m}$ during water diuresis in normal, hypothalamic diabetes insipidus (Brattleboro strain) and lithium-polyuric rats. Values are mean \pm SEM.

reported in Brattleboro rats with congenital diabetes insipidus after dehydration for $24 \mathrm{~h}$ (16).

Medullary content of electrolytes. Since washout of medullary solutes could contribute to a vasopressinresistant polyuria, the electrolyte content of renal tissue was analyzed in lithium-treated and control rats. Tissue was analyzed for water, sodium, potassium, and lithium in three groups of lithium-treated animals with differing plasma lithium concentrations and in untreated controls (Table III and Fig. 5). Plasma lithium at the time of sacrifice was varied by administering the last lithium dose $24 \mathrm{~h}$ (group 1), $8 \mathrm{~h}$ (group 2), and $4 \mathrm{~h}$ (group 3) before sacrifice. All lithium rats had polyuria equivalent to $40-60 \%$ of body weight for at least 3 days before sacrifice. Despite this polyuria, the water content of renal cortex, red medulla, white medulla, and papilla was similar in each group of lithium rats compared to nonpolyuric normal control rats. There was no washout of the corticopapillary gradient for sodium in any group of polyuric rats. Rats with the lowest serum lithium concentration (group 1, Fig. 5, upper graph) developed a modest corticomedullary gradient for lithium. In animals with the highest plasma lithium (group 3, Fig. 5, lower graph), the concentration of lithium in tissue water increased progressively from cortex to papilla, with a resulting 2.9-fold corticopapillary gradient for lithium. Expression of electrolyte content as meq/100 $\mathrm{g}$ dry solids yielded comparable values, since there was no difference between lithium and control rats in the tissue water content of each kidney zone.
Response to cyclic AMP. Each of the previous observations in patients and animals supported the hypothesis that lithium interfered with the action of vasopressin on the renal tubule. Since the action of vasopressin is presumed to be mediated by an increase in medullary $3^{\prime} 5^{\prime}$ cyclic AMP (17), experiments were performed to evaluate the effect of intravenous infusions of vasopressin and dibutyryl cyclic AMP on water diuresis in normal, Brattleboro diabetes insipidus, and lithium-treated rats (Fig. 6). A water diuresis resulting in $\mathrm{U}_{\text {osm }}$ below 100 was established in anesthetized animals as described under Methods. Intravenous infusion of vasopressin $(5-10 \mathrm{mU} / \mathrm{kg}$ in 5 min) produced a concentrated urine within 10-15 min in normal rats and Brattleboro rats with diabetes insipidus but was ineffective in concentrating the urine above plasma in all lithium rats studied.

Brief intravenous infusions of dibutyryl cyclic AMP $(15-20 \mathrm{mg} / \mathrm{kg}$ in $5 \mathrm{~min})$ produced a concentrated urine (U osm 350-550) in normal and Brattleboro rats lacking endogenous vasopressin. Comparable infusions of dibutyryl cyclic AMP into lithium rats were ineffective in concentrating the urine above plasma osmolality. Maximum $U_{o s m}$ after vasopressin and dibutyryl cyclic AMP were not significantly different $(P>0.05)$ in normal and Brattleboro rats. Although a slight increase in $U_{o s m}$ above baseline values $(P<0.05)$ occurred after dibutyryl cyclic AMP in lithium-treated rats, the urine remained hypotonic to plasma and was not accompanied by a reduction in urine flow (Table IV). In contrast urine flow rates were markedly re- 
TABLE IV

Urine Flow Rates (V) before and after Vasopressin and Dibutyryl Cyclic AMP in Normal, Brattleboro Diabetes Insipidus, and Lithium-Treated Polyuric Rats

\begin{tabular}{|c|c|c|c|c|c|c|}
\hline \multirow[b]{2}{*}{ Group } & \multirow[b]{2}{*}{$\mathrm{n}$} & \multicolumn{2}{|c|}{$\mathrm{V}$} & \multirow[b]{2}{*}{$\mathrm{n}$} & \multicolumn{2}{|c|}{$\mathrm{V}$} \\
\hline & & Prevasopressin & Postvasopressin & & Predibutyryl & $\begin{array}{c}\text { Postdibutyryl } \\
\text { cyclic AMP }\end{array}$ \\
\hline & \multicolumn{4}{|c|}{$m l / \min$} & \multicolumn{2}{|c|}{$\mathrm{ml} / \min$} \\
\hline Normal rats & 8 & $0.22 \pm 0.02$ & $0.08 \pm 0.01^{*}$ & 5 & $0.23 \pm 0.04$ & $0.09 \pm 0.01^{*}$ \\
\hline Brattleboro rats & 4 & $0.12 \pm 0.01$ & $0.05 \pm 0.01^{*}$ & 6 & $0.15 \pm 0.02$ & $0.02 \pm 0.004^{*}$ \\
\hline Lithium rats & 7 & $0.21 \pm 0.02$ & $0.22 \pm 0.03$ & 8 & $0.21 \pm 0.02$ & $0.17 \pm 0.02$ \\
\hline
\end{tabular}

${ }^{*} P<0.001$ in comparison of flow rates before and after.

duced $(P<0.001)$ after both vasopressin and dibutyryl cyclic AMP in normal and Brattleboro rats.

It was possible that vasopressin or dibutyryl cyclic AMP might have produced a concentrated urine in Brattleboro rats with diabetes insipidus because of an effect on renal circulation (e.g. to reduce GFR) rather than the usually presumed action on the permeability of collecting ducts to water. The effects of vasopressin and dibutyryl cyclic AMP on the GFR were therefore investigated in separate experiments during infusion of both agents into water-loaded Brattleboro rats. At infusion rates of vasopressin up to $13 \mathrm{mU} / \mathrm{kg} / 60 \mathrm{~min}$, GFR remained stable $(750-1,000 \mu \mathrm{l} / \mathrm{min} / 100 \mathrm{~g}$ rat $)$ in six of seven animals studied. After infusion of larger doses of dibutyryl cyclic AMP $(67-100 \mathrm{mg} / \mathrm{kg} / 60$ min) two patterns of GFR response were noted. GFR

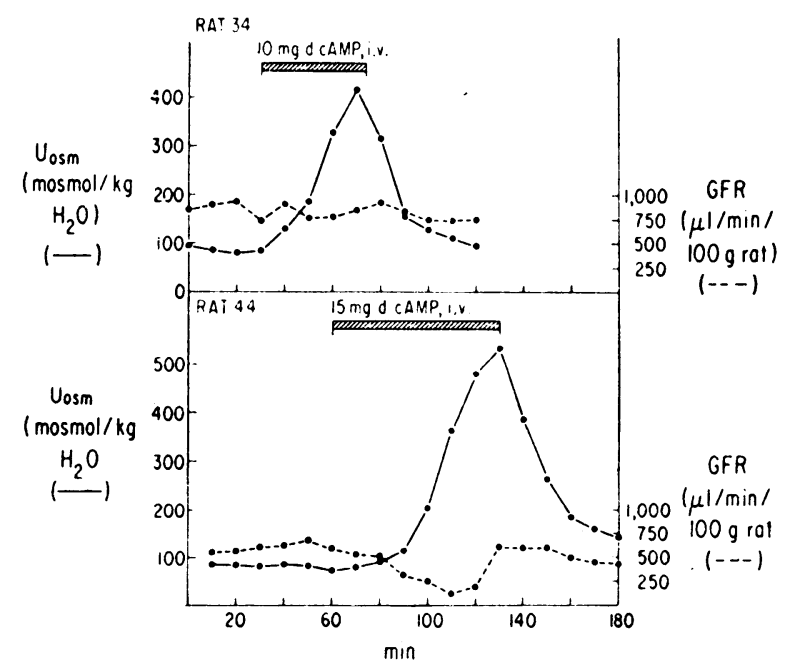

Figure 7 Patterns of response of $U_{o s m}$ and GFR after intravenous infusion of dibutyryl (d) cyclic AMP (67$100 \mathrm{mg} / \mathrm{kg}$ ) in hypothalamic diabetes insipidus rats (Brattleboro strain). Upper figure demonstrates urine concentration without change in GFR; lower figure demonstrates reduction in GFR preceding urine concentration. remained stable (Fig. 7, upper graph) in five and decreased significantly in four (Fig. 7, lower graph) of nine animals studied.

\section{DISCUSSION}

The present studies indicate that renal concentrating defects and nephrogenic diabetes insipidus are common findings in patients receiving lithium salts. Despite widespread use of this agent in several large clinical trials (1-4), polyuria was previously mentioned only as an occasional side effect. Recently Angrist, Gershon, Levitan, and Blumberg (5) reported two patients with lithium-induced polyuria and suggested a transient hypokalemic nephropathy as the cause for this defect. Lee, Jampol, and Brown (6) reported a single patient with lithium-induced polyuria and polydipsia with a persistent concentrating defect ( $U_{o s m}$ 241) 46 days after cessation of therapy. Singer, Rotenberg, and Puschett (7) reported three patients with lithium polyuria who demonstrated a normal excretion of solute-free water with marked impairment of solutefree water reabsorption after hypertonic saline and vasopressin. On the basis of these findings they suggested that the concentrating defect was most likely due to impaired water flow across the distal tubule rather than interference with sodium chloride transport in the ascending limb of the loop of Henle.

The response to therapy in the present studies confirms the nephrogenic basis of lithium polyuria in humans. Unlike patients with primary psychogenic polyuria, in whom prolonged vasopressin therapy results in concentrated urine and occasional water intoxication (18), lithium-polyuric patients failed to reduce their polyuria or increase their urine osmolality after 4 days of treatment with vasopressin tannate. Chlorpropamide, which facilitates the action of vasopressin on the distal tubule $(19,20)$ and toad bladder (21, 22) and is ineffective in nephrogenic diabetes insipidus (23-25), was likewise ineffective in these patients. The 
dramatic reduction in polyuria and increase in $U_{\text {osm }}$ after chlorothiazide administration to patients with lithium polyuria is consistent with the similar action of this agent in hereditary nephrogenic diabetes insipidus $(26,27)$. While the antidiuresis of chlorothiazide is incompletely understood, it is likely that this agent reduced the delivery of water to the distal nephron as a consequence of sodium diuresis, diminished GFR, and increased fractional reabsorption of sodium and water in the proximal tubule (28-31).

Lithium polyuria in experimental animals was first noted by Radomski, Fuyat, Nelson, and Smith in the $\operatorname{dog}$ (32) and Schou (33) in the rat. It was recently suggested that lithium polyuria in the rat resulted from excessive intake of water (34). The present experiments exclude this explanation. If concentrating ability were reduced as a result of excessive intake of water, the response to vasopressin should be similar in rats with lithium polyuria and rats with comparable polyuria induced by glucose drinking. Instead, chronic lithium-treated animals showed little response to large doses of vasopressin, which produced a concentrated urine in rats drinking glucose. Like rats with pituitary diabetes insipidus, lithium rats were able to achieve a concentrated urine after prolonged dehydration, suggesting that at low flow rates in the distal tubule and collecting ducts, lithium did not prevent partial equilibration of tubular fluid with the hypertonic interstitium.

A possible mechanism for the defect in urinary concentration induced by lithium is that the transport and sequestration of sodium in the medulla and papilla might be disrupted. This seems unlikely because of the finding in this study of a normal corticopapillary gradient for sodium and a normal papillary water content in each of three groups of lithium-polyuric rats. Studies by Valtin in Brattleboro diabetes insipidus rats (16) showed a normal corticopapillary gradient for sodium expressed in meq/100 $\mathrm{g}$ dry solids, normal water content in cortex and medulla, but an increase in water content in papillary tissue. Differences in papillary water content in these studies may be related to the higher urine flow in Brattleboro rats, which excreted up to $100 \%$ of body weight in a $24-\mathrm{h}$ urine as compared to $40-60 \%$ of body weight in lithium rats in the present study.

The ability of the rat kidney to establish a corticopapillary gradient for lithium was demonstrated in the present studies. Solomon reported a similar gradient for lithium, but not rubidium or cesium, in the dog kidney after isotonic infusion of each alkali metal salt (35). Lithium-induced polyuria was noted in all rats in comparison to less than a third of human subjects studied, despite similar plasma lithium concentrations (0.4-1.5 meq/liter) in both species. The capacity of rodents to establish higher concentrations of papillary sodium, and presumably lithium, in comparison to man could result in increased lithium concentrations at the sites of action of vasopressin in the rat. In our studies and those of Solomon (35) lithium did not alter the cortico-papillary gradient for sodium, suggesting that this cation does not interfere with the mechanisms by which a sodium gradient is established in the renal medulla.

These experiments supported the theory that lithium directly interferes with the action of vasopressin on the distal tubule and collecting duct of the rat. This hypothesis was explored further by investigating the effects of intravenous infusions of vasopressin and dibutyryl cyclic AMP in rats. Short infusions of vasopressin, sufficient to inhibit a water diuresis and concentrate the urine in the Brattleboro rat (with a known reduction in papillary hypertonicity) were ineffective in lithium-polyuric rats. This effect of lithium could result from interference with the mediation of vasopressin at any known step within the renal tubular cell, including the adenyl cyclase receptor site, the rate of formation of cyclic AMP, the level of phosphodiesterase activity, or the activation of a protein kinase. Dibutyryl cyclic AMP infusions produced a concentrated urine in normal and Brattleboro rats. Infusions of dibutyryl cyclic AMP were, however, ineffective in concentrating the urine in lithium-treated rats. These findings suggest that at least one action of lithium includes interference with the cellular mediation of vasopressin at a step beyond the formation of cyclic AMP.

It must be noted that the capacity of intravenous cyclic AMP or its dibutyryl derivative to mimic vasopressin in vivo has heretofore been open to question (36). This effect has been suggested in man (37) and the rabbit (38) but changes in GFR were not excluded in these studies. At the doses employed in the present studies dibutyryl cyclic AMP interrupted a water diuresis in Brattleboro rats with both stable and reduced GFRs. The possibility is not entirely excluded that antidiuresis in Brattleboro rats with diabetes insipidus was the result of some unmeasured change in the renal circulation or of the release of oxytocin from the hypothalamus.

An effect of lithium on vasopressin-stimulated adenyl cyclase is not excluded by these studies. In vitro data indicate that lithium may inhibit the stimulation of adenyl cyclase in brain (39), thyroid (40), and kidney tissue (10), and Dousa has recently reported that 5-30 $\mathrm{mM} \mathrm{LiCl}$ inhibited vasopressin-stimulated adenyl cyclase prepared from human renal medullary tissue (12). Studies in thyroid tissue also suggest that lithium may interfere with hormone function at more than one site of the adenyl cyclase effector sequence. Lithium is capable of inhibiting stimulation of thyroid adenyl 
cyclase by thyroid-stimulating hormone (TSH) (41). In addition, low doses of lithium given in vivo inhibit colloid droplet formation in response to dibutyryl cyclic AMP as well as to TSH (42), suggesting a block subsequent to cyclic AMP formation. The action of lithium to block antidiuretic hormone-stimulated transport of water or sodium by the toad urinary bladder has been placed both before cyclic AMP formation (7) and after this step $(8,9)$ by conflicting experiments in different laboratories.

\section{ACKNOWLEDGMENTS}

The authors thank Mrs. Nadia Myketey, Mrs. Gertruida Klein-Robbenhaar, and Mrs. Adele Powell for their valued technical assistance.

This investigation was supported by Public Health Service grants $\mathrm{HL}-00834, \mathrm{AM} 5015$ and $\mathrm{K} 6-\mathrm{AM}-21578$ to $\mathrm{Dr}$. Epstein, and by the Veterans Administration.

\section{REFERENCES}

1. Schou, M. 1959. Lithium in psychiatric therapy. Psychopharmacologia. $1: 65$.

2. Maggs, R. 1963. Treatment of manic illness with lithium carbonate. Br. J. Psychiatr. 109: 56.

3. Fieve, R. R., S. R. Platman, and R. R. Plutchik. 1968. The use of lithium in affective disorders. I. Acute endogenous depression. Am. J. Psychiatr. 125: 487.

4. Bunney, W. E., F. K. Goodwin, J. M. Davis, and J. A. Fawcett. 1968. A behavioral-biochemical study of lithium treatment. Am. J. Psychiatr. 125: 499.

5. Angrist, B. M., S. Gershon, S. J. Levitan, and A. G. Blumberg. 1970. Lithium-induced diabetes insipiduslike syndrome. Compr. Psychiatr. $11: 141$.

6. Lee, R. V., L. M. Jampol, and W. V. Brown. 1971. Nephrogenic diabetes insipidus and lithium intoxication. Complications of lithium carbonate therapy. N. Engl. J. Med. $284: 93$.

7. Singer, I., D. Rotenberg, and J. B. Puschett. 1972. Lithium-induced nephrogenic diabetes insipidus: in vivo and in vitro studies. J. Clin. Invest. 51: 1081.

8. Harris, C. A., and F. A. Jenner. 1972. Some aspects of the inhibition of the action of antidiuretic hormone by lithium ions in the rat kidney and bladder of the toad Bufo marinus. Br. J. Pharmacol. 44: 223.

9. Bentley, P. J., and A. Wasserman. 1972. The effect of lithium on the permeability of an epithelial membrane, the toad urinary bladder. Biochim. Biophys. Acta. 266: 285.

10. Singer, I., and E. A. Franko. 1973. Lithium-induced $\mathrm{ADH}$ resistance in toad urinary bladder. Kidney Int. 3: 151 .

11. Dousa, T., and O. Hechter. 1970. The effect of $\mathrm{NaCl}$ and $\mathrm{LiCl}$ on vasopressin-sensitive adenyl cyclase. Life Sci. $9: 765$.

12. Dousa, T. P. 1972. The effect of lithium on the cellular action of $\mathrm{ADH}$ in human kidney. V. International Congress of Nephrology, Mexico City. 79. (Abstr.)

13. Miller, M., T. Dalakos, A. M. Moses, H. Fellerman, and D. H. P. Streeten. 1970. Recognition of partial defects of antidiuretic hormone secretion. Ann. Intcrn. Med. $73: 721$.

14. Manitius, A., H. Levitin, D. Beck, and F. H. Epstein. 1960. On the mechanism of impairment of renal concentrating ability in potassium deficiency. J. Clin. Invest. $39: 684$.

15. Gaunt, R., J. J. Chart, and A. A. Benzi. 1963. Interaction of drugs with endocrines. Annu. Rev. Pharmacol. 3: 109 .

16. Valtin, H. 1966. Sequestration of urea and nonurea solutes in renal tissue of rats with hereditary hypothalamic diabetes insipidus: effect of vasopressin and dehydration on the counter-current mechanism. J. Clin. Invest. $45: 337$.

17. Orloff, J., and J. Handler. 1967. The role of adenosine $3^{\prime} 5^{\prime}$ phosphate in the action of antidiuretic hormone. Am. J. Med. 42: 757.

18. Barlow, E. D., and H. E. de Wardener. 1959. Compulsive water drinking. Quart. J. Med. 28: 235.

19. Miller, M., and A. M. Moses. 1970. Potentiation of vasopressin action by chloropropamide in vivo. Endocrinology. 86: 1024 .

20. Berndt, W. O., M. Miller, W. Kettyle, and H. Valtin. 1970. Potentiation of the antidiuretic effect of vasopressin by chlorpropamide. Endocrinology. 86: 1028.

21. Ingelfinger, J. R., and R. M. Hayes. 1969. Evidence that chlorpropamide and vasopressin share a common site of action. J. Clin. Endocrinol. Metab. 29: 738.

22. Mendoza, S. A. 1969. Effect of chlorpropamide on the permeability of the urinary bladder of the toad. Endocrinology. $84: 411$.

23. Arduino, F., F. J. P. Ferraz, and J. Rodrigues. 1966. Antidiuretic action of chlorpropamide in idiopathic diabetes insipidus. J. Clin. Endocrinol. Metab. 26:1325.

24. Froyshov, I., and H. N. Haugen. 1968. Chlorpropamide treatment in diabetes insipidus. Acta Med. Scand. 183: 397.

25. Webster, B., and J. Bain. 1970. Antidiuretic effect and complications of chlorpropamide therapy in diabetes insipidus. J. Clin. Endocrinol. Metab. 30: 215.

26. Crawford, J. D., and G. Kennedy. 1959. Chlorothiazide in diabetes insipidus. Nature (Lond.). 183: 891.

27. Crawford, J. D., G. C. Kennedy, and L. E. Hill. 1960 Clinical results of treatment of diabetes insipidus with drugs of the chlorothiazide series. N. Engl. J. Med. 262: 737 .

28. Earley, L. E., and J. Orloff. 1962. The mechanism of antidiuresis associated with administration of hydrochlorothiazide to patients with vasopressin-resistant diabetes insipidus. J. Clin. Invest. 41: 1988.

29. Kleeman, C. R. 1972. Water metabolism. In Clinical Disorders of Fluid and Electrolyte Metabolism. M. H. Maxwell and C. R. Kleeman, editors. McGraw-Hill Book Company, New York. 2nd edition. 276.

30. Morgan, T., and H. E. de Wardener. 1969. Antidiuresis in diabetes insipidus. Lancet. 1: 524.

31. Laszio, F. A., L. Czako, I. Szijj, and R. Kovacs. 1970. Response to saluretics and oral antidiabetics in diabetes insipidus and psychic polydipsia. Acta Med. Acad. Sci. Hung. 27: 45.

32. Radomski, J. L., H. N. Fuyat, A. A. Nelson, and P. K. Smith. 1950. The toxic effects, excretion and distribution of lithium chloride. J. Pharmacol. Exp. Ther. 100: 429. 
33. Schou, M. 1958. Lithium studies. I. Toxicity. Acta Pharmacol. Toxicol. 15 : 70.

34. Smith, D. F., S. Balagura, and M. Lubran. 1970. "Antidotal Thirst": a response to intoxication. Science (Wash., D. C.). 167 : 297.

35. Solomon, S. 1967. Action of alkali metals on papillarycortical sodium gradient of dog kidney. Proc. Soc. Exp. Biol. Med. 125 : 1183.

36. Liddle, G. W., and J. G. Hardman. 1971. Cyclic adenosine monophosphate as a mediator of hormone action. N. Engl. J. Med. 285 : 560.

37. Levine, R. A. 1968. Antidiuretic responses to exogenous adenosine $3^{\prime} 5^{\prime}$ monophosphate in man. Clin. Sci. (Oxf.). $34: 253$.

38. Barraclough, M. A., and N. F. Jones. 1970. Effects of adenosine $3^{\prime} 5^{\prime}$ monophosphate on renal function in the rabbit. Br. J. Pharmacol. 40: 334.

39. Dousa, T., and O. Hechtor. 1970. Lithium and brain adenyl cyclase. Lancet. 1 : 834.

40. Burke, G. 1970. Effects of cations and ouabain on thyroid adenyl cyclase. Biochim. Biophys. Acta. 220: 30.

41. Wolff, J., S. C. Berens, and A. B. Jones. 1970. Inhibition of thyrotropin-stimulated adenyl cyclase activity of beef thyroid membranes by low concentrations of lithium ion. Biochem. Biophys. Res. Commun. 39: 77.

42. Williams, J. A., S. C. Berens, and J. Wolff. 1971. Thyroid secretion in vitro: inhibition of TSH and dibutyryl cyclic AMP-stimulated ${ }^{181} \mathrm{I}$ release by $\mathrm{Li}^{+}$. Endocrinology. 88: 1385. 